\title{
Zooplankton community attributes in an oligo-mesotrophic reservoir: A comparative study of two sampling strategies
}

\section{RAFAEL L. MACÊDO ${ }^{1}$, VANESSA G. LOPES ${ }^{2}$, BETINA KOZLOWSKY-SUZUKI ${ }^{3}$ and CHRISTINA W.C. BRANCO ${ }^{1}$}

${ }^{1}$ Núcleo de Estudos Limnológicos, Departamento de Zoologia, Instituto de Biociências, Centro de Ciências Biológicas e da Saúde, Universidade Federal do Estado do Rio de Janeiro/UNIRIO, Av. Pasteur, 458, 22290-240 Rio de Janeiro, RJ, Brazil

${ }^{2}$ Laboratório de Ecologia Teórica e Síntese/LETS, Instituto de Ciências Biológicas/ICB, Universidade Federal de Goiás/UFG, Av. Esperança, s/n, 64690-900 Goiânia, GO, Brazil

${ }^{3}$ Departamento de Ecologia e Recursos Marinhos, Instituto de Biociências, Centro de Ciências Biológicas e da Saúde, Universidade Federal do Estado do Rio de Janeiro/UNIRIO, Av. Pasteur, 458, 22290-240 Rio de Janeiro, RJ, Brazil

Manuscript received on October 13, 2017; accepted for publication on May 31, 2018

How to cite: MACÊDO RL, LOPES VG, KOZLOWSKY-SUZUKI B AND BRANCO CWC. 2019. Zooplankton community attributes in an oligo-mesotrophic reservoir: A comparative study of two sampling strategies. An Acad Bras Cienc 91: e20170807. DOI 10.1590/0001-3765201820170807.

Abstract: Studies of the limnetic zooplankton in Brazilian freshwater have been done using several sampling strategies which are frequently associated to personal preferences, system constraints and objectives of the studies. It is known that a better sampling technique exists for each group of investigated zooplankton. So, the challenge is to provide a good sampling method for all groups at once. Regarding this theme we are contributing by pointing out the merits and demerits of two collecting methods of zooplankton widely used in many studies in Brazilian reservoirs to clarify the information about communities' structure in past published and non-published biological data and also find a more useful sampler for future studies. Two simultaneous strategies were used with a $68 \mu \mathrm{m}$-plankton net: filtration of water collected at subsurface by bucket and vertical hauls throughout the euphotic zone. A total of 133 taxa was found with both strategies. Rotifers (69 taxa) comprised the group with the highest richness, followed by protozoans (31 taxa), cladocerans (30 taxa) and copepods (5 taxa). Paired t-tests showed significant difference for richness despite none for density in whole period. Spatially, sampling strategies differed in abundance and composition of zooplankton at most sites sampled (except for L1- shallowest site and L4 - deepest site). Temporally, both samplers showed the highest mean abundances at thermal stratification period. In general, the extent of spatial data collected throughout the vertical gradient provided better estimations in the limnetic area for the attributes analyzed: zooplankton density, richness, specific diversity, equitability and cumulative richness. Zooplankton sampling by vertical hauls through the euphotic zone was more efficient, but in order to obtain integrated data and according to the collector's curve it might be useful to adopt both methodologies.

Key words: bucket sampling, freshwater mesozooplankton, plankton collection methods, sub-sampling, vertical hauls.

Correspondence to: Rafael Lacerda Macêdo

E-mail: limnologist261@gmail.com

ORCid: http://orcid.org/0000-0001-5086-0170 


\section{INTRODUCTION}

Zooplankton communities can vary over both spatial and temporal gradients and this variation is often difficult to be quantified statistically (Evans and Sell 1983, Livings et al. 2010). This variability may affect the accuracy and precision of the estimation of zooplankton populations and the diagnosis of community shifts in response to local gradients and temporal environmental changes. Sampling strategies that do not consider spatial and temporal structuring of communities lead to poorly designed surveys that may significantly underestimate diversity (Vieira et al. 2017).

Studies of the limnetic zooplankton in Brazilian natural lakes and reservoirs have been done using several sampling strategies such as collecting a known volume of sub-surface water by bucket or by bottle-sampler and filtration through a plankton net (Rocha et al. 2002, Almeida et al. 2006, 2009, Peixoto et al. 2008, Nadai and Henry 2009), collecting with a suction pump (Sampaio et al. 2002, Takahashi et al. 2005, Santos-Wisniewski and Rocha 2007, Serafim-Jr et al. 2010), sampling at several depths using a Van Dorn bottle followed by filtration (Starling 2000, Maia-Barbosa et al. 2003, Keppeler 2003), collection by vertical hauls with a plankton net at specific layers of the water column (Maia-Barbosa and Bozelli 2005, Sendacz et al. 2006, Nogueira et al. 2008, Simões and Sonoda 2009, Silva et al. 2014), horizontal hauls at surface (Waichman et al. 2002) or sampling using a Schindler-Patalas trap (Pinto-Coelho et al. 2005, Bezerra-Neto et al. 2009). These varieties of techniques are frequently also associated to personal preferences, system constraints and the objectives of different zooplankton community studies (Mack et al. 2012).

It is known that a best sampling technique exists for each group of zooplankton investigated (for example: macrozooplankton - large mesh net, microzooplankton - small mesh nets (MacGowan and Fraundorf 1966, Vannucci 1968), and protozoasurface collections (Lahr and Lopes 2006). While species richness and evenness are usually dependent on mesh size, diversity indexes are typically less influenced by mesh selection (Riccardi 2010, Wu et al. 2011). The fact is that the effectiveness of filter material for the separation of plankton size fractions has been discussed since long (Evans and Sell 1985, Logan 1993, Hwang et al. 2007, Wu et al. 2011). So, the challenge is to provide a good sampling method for all groups at once.

Kozlowsky-Suzuki and Bozelli (1998) compared the efficiency of three different samplers (vertical haul, Schindler-Patalas trap and suction pump) in a Brazilian coastal lagoon. The performance of the vertical haul with plankton net was the lowest, except for the copepods, and the sampling with suction pump was considered the most efficient for all the taxa analyzed. However, several authors agree that adopting only a single collecting strategy might not satisfactorily sample all components of the zooplankton community (Hodgkiss 1977, Starling 2000, Livings et al. 2010).

Vertical haul has been the most used technique in studies of zooplankton communities in reservoirs, and according to Tonolli (1971) it is the method that achieves the most accurate representation of the total plankton present in the water column, since it enables a larger volume of water to be sampled at various depths. The collection by suction pump, despite filtering large volumes of water in a short time, has limitations in terms of selectivity of zooplankton taxa and is not optimal in deep systems. The continuous constant flow selects a larger quantity of poor swimmers, the suction may damage illoricated rotifers or address the problem of collecting live specimens for mortality determination (Icanberry and Richardson 1973), and the narrow diameter of the collector tube helps the scape of the good swimmers. Furthermore, as discussed by Di Bernardi (1984) suction by pump precludes the knowledge on the heterogeneous or 
in mosaic distribution of the zooplankton, as well as the vertical haul.

However, both the vertical hauls and the collection of large volumes of water through the suction pump can be impractical in eutrophic reservoirs due to the ease clogging of the plankton net by phytoplankton. In particular when the mesh $<200 \mu \mathrm{m}$ is used, the high biomass of phytoplankton such as cyanobacteria colonies and/or filaments often impair filtration of large volumes of water. In these environments, the most used strategy for zooplankton sampling has been the collection of a small volume of water for further filtration, as in the studies of Rocha et al. (2002) and Branco et al. (2002) in the Funil reservoir (20L), Branco and Senna (1996) in Lake Paranoá (20L) or by the Schindler-Patalas trap $(5.1 \mathrm{~L})$ as in the study of Pinto-Coelho et al. (2005) in the Pampulha reservoir. However, in addition to the low volume, another question has been considered Schwoerbel (1970) when using collection by bottles, buckets or traps that although efficient in collecting in specific strata of water column, provides a random sample from a part of the water with obvious loss of plankton nearby.

Much research has been conducted to quantify and characterize zooplankton communities in Brazilian reservoirs and the improvement of available methods in plankton studies, comparison of ongoing sampling strategies and the choice of the best approach for each ecosystem can upgrade environmental monitoring since zooplankton is considered to be an important and integrated component of the pelagic food web giving support to environmental managers' decisions. According to Jeppesen et al. (2011) when selecting the right metrics, zooplankton are cost-efficient indicators of the trophic status and ecological quality of lakes.

Herein, we compare two methods of zooplankton collection using plankton net of $68 \mu \mathrm{m}$ : vertical hauls all through the euphotic zone and the collection of $20 \mathrm{~L}$ of subsurface water by bucket and immediate filtration. Here, we aim at characterizing in the zooplankton community at two different environments in the water column based on two different sampling methods at an oligo-mesotrophic reservoir considering attributes such as richness, abundance, frequency of occurrence, evenness and diversity of taxa.

We predict that the method of collecting zooplankton at the subsurface, although more agile, practical and adopted in systematic monitoring in many eutrophic reservoirs might significantly subsample the zooplankton community in limnetic area of this oligo-mesotrophic reservoir. This could be due to the smaller sampling area (subsurface), not to mention the probable greater escape of mobile taxa.

\section{MATERIALS AND METHODS}

\section{STUDY AREA}

Ribeirão das Lajes Reservoir is located in the southeast part of Brazil (22 $43^{\circ} \mathrm{S}$ and $22^{\circ} 46^{\prime} \mathrm{S}$; $44^{\circ} 30^{\prime} \mathrm{W}$ and $44^{\circ} 60^{\prime} \mathrm{W}$ ) and it was built in 1908 as the first impoundment constructed in the Rio de Janeiro State (Fig. 1). The reservoir lies at $415 \mathrm{~m}$ a.s.1. in a relatively undisturbed area mostly surrounded by rain forest, with a few cattle farms and a fishing club. Although primarily a hydropower reservoir, it is also used for domestic and industrial supply, irrigation, aquaculture and recreation. The lake has a surface area of $30.73 \mathrm{~km}^{2}$, an average depth of $15 \mathrm{~m}$, a residence time of more than 300 days, an accumulated volume of $450 \times 10^{6} \mathrm{~m}^{3}$, and it is considered as an oligo-mesotrophic system (Guarino et al. 2005, Soares et al. 2008).

\section{SAMPLING AND PROCESSING}

Zooplankton samples were taken monthly at five stations along the reservoir from May 2011 to June 2012, totalizing 13 months (Fig. 1). Those five sites were selected for having been previously used in systematic monitoring analysis (Lopes 


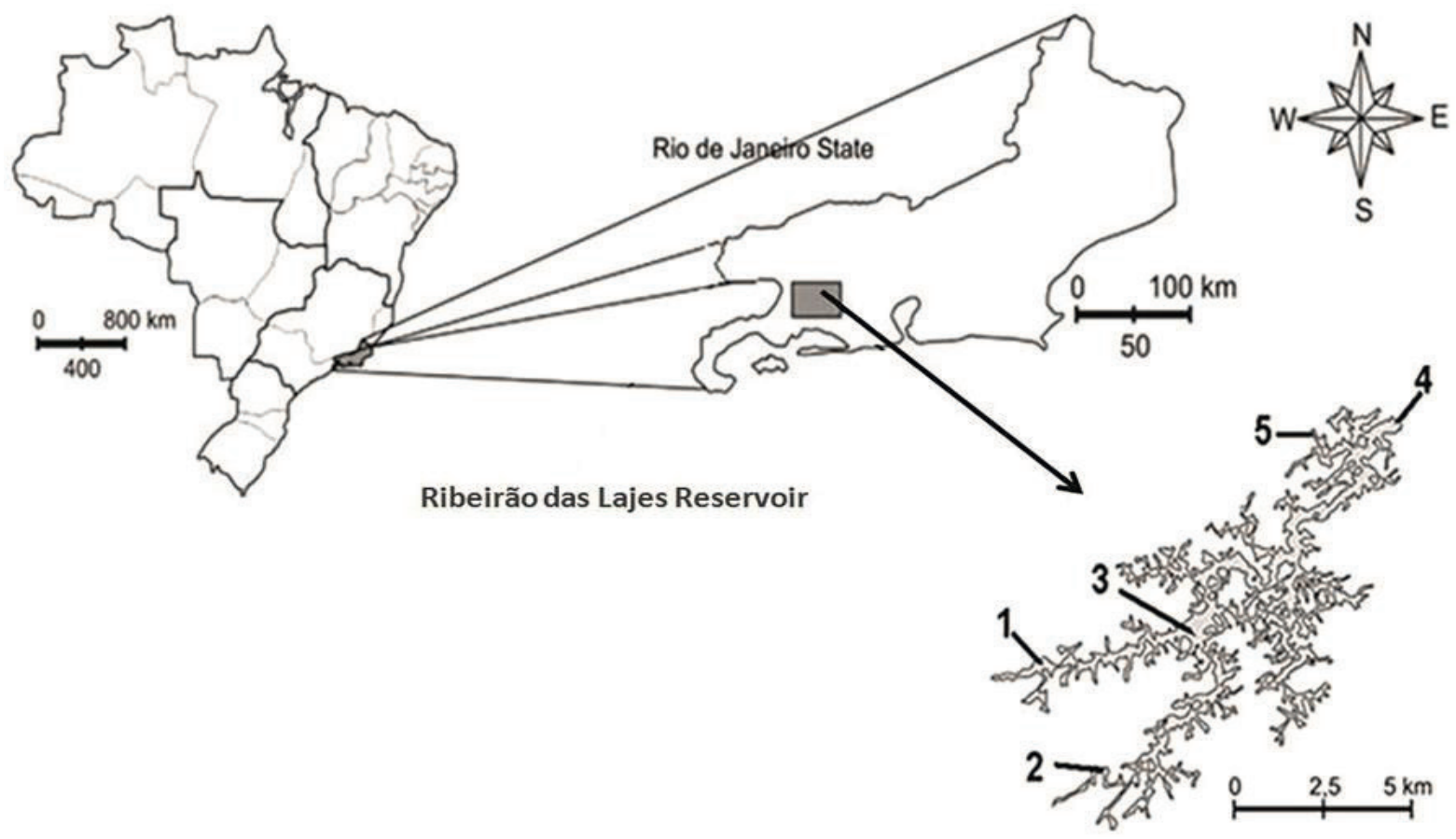

Figure 1 - Ribeirão das Lajes Reservoir, Rio de Janeiro, showing the position of the five sampling stations.

et al. 2017) and for providing gradients of trophic state, different abiotic variables and hydrodynamics. Sampling site L1 is located close to the main tributary, lotic and shallow with suspend organic matter. Site L2 near a small creek and with high primary productivity as L3, both intermediate zones. L5 is semi lotic site with presence of pisciculture promoting the supply of nutrients from fish feeding, and site L4 is near the dam, lentic and 40 meters deep with high transparency and euphotic zone. The comparisons were made between two sampling strategies, characterizing the attributes of two different environments, the subsurface by bucket and the full euphotic zone by vertical hauls. A total of 65 samples were analyzed with each sampling strategy. Quantitative analyses were done in replicates with two different methods. Zooplankton was sampled by filtration of $20 \mathrm{~L}$ of water taken by bucket at sub-surface through a net of $68 \mu \mathrm{m}$ mesh size and by vertical hauls of a known volume in the euphotic zone of the reservoir using the same plankton net (Table I). The depth of the lower limit of the euphotic zone was estimated through the measure of the Secchi disk depth multiplied by 2.7 (Esteves 2011). Samplings with both methods were performed simultaneously, and therefore the environmental conditions were considered similar even though the sampling layer in the water column was different. All samples were preserved with a sugar-formalin (Haney and Hall 1973 ) at 4\% final concentration. Zooplankton was identified to the species level whenever possible using specific literature. Zooplankton abundance was estimated by counting the organisms, in subsamples of $1 \mathrm{~mL}$, in a Sedgewick-Rafter cell, using an optical microscope. Specimens were examined for identification and counted at 20-40X magnification. Each bucket sample was counted entirely, whereas $30 \%$ of the concentrate of each sample taken with vertical hauls was counted due to the high density of individuals (Karjalainen et al. 1996, Rahkola-Sorsa et al. 2014). 


\section{DATA ANALYSIS}

The accumulative frequency of taxa was obtained from a k-curve on R software (Table II). Zooplankton diversity was assessed from Shannon \& Weaver diversity and Pielou's evenness, those indexes were calculated in Excel. We used paired t-tests to compare differences in mean zooplankton density and richness per month between strategies types. Homoscedasticity was verified by Levene test. Coefficient of variation was used to estimate precision of the sampling methods. In order to analyze sampling strategies concordance, we performed a procrustes analysis (PROTEST - Jackson 1995) coupled with Principal Coordinate Analysis (PCoA) (Legendre and Legendre 1998) on R software. This analysis consists in a comparison between community-based ordinations by using a rotational-fit algorithm that minimizes the sum-of-the squares residuals between the ordinations. We used the Protest to compare richness (qualitative) and abundance (quantitative) data. The species accumulation curve (Fig. 2) and

\section{TABLE I}

Total filtered water volume per site based on the limit of the euphotic zone. Sampled volumes for the vertical haul varied according to the size of euphotic zone. Therefore, the lengths varied from 1.62 to 15 meters.

\begin{tabular}{lccccc}
\hline \multicolumn{5}{c}{ Filtered water column per site (liters) } \\
$\begin{array}{l}\text { month/ } \\
\text { sites }\end{array}$ & L1 & L2 & L3 & L4 & L5 \\
May/11 & 333.82 & 715.33 & 429.20 & 553.19 & 333.82 \\
June & 305.21 & $1,335.29$ & 953.78 & 667.64 & 667.64 \\
Aug & 333.82 & $1,144.53$ & 763.02 & $1,335.29$ & 381.51 \\
Sept & 381.51 & 619.95 & 619.95 & 858.40 & 619.95 \\
Oct & 143.07 & 524.58 & 476.89 & 476.89 & 476.89 \\
Nov & 190.76 & 476.89 & 476.89 & 667.64 & 476.89 \\
Dec & 238.44 & 381.51 & 381.51 & 476.89 & 476.89 \\
Jan & 38.15 & 305.21 & 457.81 & 610.42 & 557.00 \\
Feb & 324.28 & 305.21 & 667.64 & 782.10 & 476.89 \\
Mar & 72.49 & 377.69 & 549.37 & 553.19 & 301.39 \\
Apr & 326.19 & 778.28 & 701.98 & 705.79 & 568.45 \\
May & 412.03 & 681.00 & 797.36 & 904.18 & 701.98 \\
June/12 & 534.11 & 942.33 & $1,110.19$ & $1,093.03$ & 553.19 \\
\hline
\end{tabular}

k-curve of cumulative dominance (Fig. 3) were also used to compare the efficiency of the samplers, and also as measurements of biodiversity (Jennings et al. 2001).

\section{RESULTS}

\section{ZOOPLANKTON COMMUNITY STRUCTURE}

A total of 133 zooplankton taxa were found belonging to five main groups (protozoans, rotifers, cladocerans, copepods and others). The most representative group was rotifers (68 taxa) followed by protozoans (31 taxa), cladocerans (30 taxa) and copepods (4 taxa). This last group was divided according to stages of development in nauplii, copepodites and adults of both cyclopoids and calanoids.

The zooplankton community of Ribeirão das Lajes Reservoir was characterized by a dominance of juvenile forms of copepods, true-planktonic rotifer taxa such as Kellicottia bostoniensis, Keratella cochelaris, K. americana, Conochilus unicornis, C. coenobasis, C. dossuarius, Ptygura libera, Ptygura sp., Collotheca ornata, Proales sp., and Ascomorpha sp., and by the smallsized cladoceran $(<0.5 \mathrm{~mm})$ Bosmina hagmani, the medium-sized cladocerans $(0.5-1.0 \mathrm{~mm})$ Ceriodaphnia silvestrii, C. paradoxa, C. cornuta, and Diaphanosoma brevireme and the larger (>1.2mm) Daphnia gessneri.

The three species of cyclopoids (Thermocyclops decipiens, Mesocyclops longisetus, Microcyclops anceps) were counted together because of identification difficulties. Only one species of calanoid was found (Notodiaptomus cearensis). Harpacticoid copepods were not identified at the specific level because of the low presence of adults. The group considered as "others" comprised meroplanktonic forms such as insect larvae, and several other invertebrates commonly found in the water column of the reservoir such as hydrachnidians, platyhelminthes and oligochaetes. We collected 15 
taxa from the group "others" and only two were common with both strategies, Chaoborus larvae and turbellarians. Vertical hauls collected 107 taxa including rotifers, cladocerans, copepods and protozoans. On the other hand, the bucket collected 80 taxa within the same groups. Only 48 taxa were commonly collected with both samplers.

Difflugia gramen and Centropyxis aculeata were the most abundant protozoan taxa found in surface samplings while Epystilis sp., Astylozoon sp. and Centropyxis aculeata were the most abundant using vertical hauls.

We didn't include copepods to estimate diversity. Copepods were only used to compare the community's structure through development stages (nauplius, copepodite and adult) and by main orders (cyclopoida, calanoida and harpacticoida). However, the four identified species were countered for richness.

Among rotifers, the highest abundance at surface was shown by Kellicottia bostoniensis and Pytgura libera and with vertical hauls by Proales sp. Ceriodaphnia silvestrii, which was the most abundant among cladocerans at surface, was rarely found in the vertical haul samples. The most abundant taxa with both methods were: Kellicottia bostoniensis, Keratella cochlearis, for rotifers, and Bosmina hagmani and Ceriodaphnia paradoxa for cladocerans. Among copepods, cyclopoid and calanoid nauplii presented high abundance varying from $83-100 \%$.

\section{ZOOPLANKTON RICHNESS AND DENSITY}

Zooplankton total richness was significantly different between the sampling strategies $(t=-9.02$, $\mathrm{p}$-value $<0.001)$ although density was not $(\mathrm{t}=0.96$, $\mathrm{p}$-value $=0.3416)$. Mean richness was 17 taxa sampling at surface by bucket, with a maximum of 36 taxa in September while the vertical haul attained an average of 26 taxa with a maximum of 40 taxa in November (Table II). Mean zooplankton density was 24,246 and 19,377 ind. $m^{-3}$ for bucket and vertical haul, respectively. Maximum density was attained at different months, 189,150 ind. $\mathrm{m}^{-3}$ in May 2012 for bucket sampling and 143,520 ind. $\mathrm{m}^{-3}$ in August 2011 for vertical haul. Dispersion of the community data $(\mathrm{CV})$ was lower for the vertical hauls than for the bucket (Table II).

Correlations were done between the filtered volume and the abundancies for both methods. Apparently, there's no relationship between the increase from the filtered volume followed by higher abundancies $(\mathrm{R}=0.25509)$.

Species accumulation curves (SAC) showed that 69 species were recorded by subsurface samples, whereas the vertical hauls collected up to 83 species. The asymptote for this SACs was 133 species but this number would have only been recorded by those methods together (Fig. 2a).

The Shannon index H' $(\log 10)$ also indicated that the vertical haul samples were more diverse than the bucket. The highest values for that index were from vertical haul except for October/11 (Table III). According to (Ludwig and Reynolds 1988), Pielou's evenness index indicates the level of distribution of individuals in their habitats and that variable was highest for the bucket in May, June and November/11 and January and March/12. In general, both methodologies showed uniform distribution of individuals among the species despite high abundance of copepods.

The k-dominance analysis shows that the bucket curve (blue) ends when x-axis hits 58 species representing a community with low diversity. On the other hand, the curve of vertical haul (red) collects faster and a larger number of species (Fig. 3).

Sampling strategies have differently characterized the community structure (Table IV). For the bucket 49 taxa account for $100 \%$ of the community in terms of abundance. In addition, rotifers appear more among the most representative in rank. For vertical haul, 60 taxa contributed for 
TABLE II

Total monthly zooplankton species richness (a) and density in ind. $\mathrm{m}^{-3}$ (b) (maximum, mean, standard deviation and coefficient of variation) in samples collected by bucket and by vertical haul.

\begin{tabular}{|c|c|c|c|c|c|c|c|c|}
\hline \multirow[t]{3}{*}{ (a) } & \multicolumn{7}{|c|}{ Richness } & \\
\hline & \multicolumn{3}{|c|}{ Bucket } & \multirow[b]{2}{*}{ cv } & \multicolumn{4}{|c|}{ Vertical haul } \\
\hline & $\max$ & mean & sd & & $\max$ & mean & sd & cv \\
\hline May/11* & 22 & 16 & 5 & 0.31 & 29 & 32 & 3 & 0.09 \\
\hline June/11 & 20 & 19 & 4 & 0.21 & 34 & 27 & 3 & 0.11 \\
\hline Aug/11 & 32 & 18 & 6 & 0.33 & 35 & 27 & 4 & 0.15 \\
\hline Sept/11 & 36 & 19 & 6 & 0.32 & 35 & 27 & 4 & 0.15 \\
\hline Oct $/ 11$ & 30 & 19 & 9 & 0.47 & 38 & 25 & 14 & 0.56 \\
\hline Nov/11* & 22 & 13 & 4 & 0.31 & 40 & 28 & 5 & 0.18 \\
\hline Dec/11* & 29 & 13 & 8 & 0.62 & 29 & 28 & 2 & 0.07 \\
\hline $\operatorname{Jan} / 12 *$ & 16 & 14 & 2 & 0.14 & 30 & 30 & 6 & 0.20 \\
\hline Feb/12* & 17 & 17 & 2 & 0.12 & 32 & 29 & 6 & 0.21 \\
\hline Mar/12 & 22 & 18 & 3 & 0.17 & 30 & 27 & 4 & 0.15 \\
\hline Apr/12 & 29 & 21 & 11 & 0.52 & 30 & 24 & 3 & 0.13 \\
\hline May/12* & 25 & 17 & 6 & 0.35 & 33 & 28 & 6 & 0.21 \\
\hline June/12 & 21 & 21 & 4 & 0.19 & 31 & 27 & 4 & 0.15 \\
\hline
\end{tabular}

* Indicated a significant difference $(\mathrm{p}<0.05)$. The zooplankton richness between paired bucket and vertical haul samples.

\begin{tabular}{ccccccccc}
\hline (b) & \multicolumn{7}{c}{ Abundance } \\
\hline & max & mean & sd & cv & max & mean & sd & cv \\
\hline May/11 & 50,501 & 17,06 & 20,081 & 1.18 & 68,35 & 35,387 & 26,485 & 0.75 \\
June/11 & 11,1 & 24,61 & 4,256 & 0.17 & 63,52 & 20,565 & 25,858 & 1.26 \\
Aug/11 & 71 & 17,75 & 32,132 & 1.81 & 143,52 & 44,546 & 57,283 & 1.29 \\
Sept/11 & 101,5 & 55,65 & 36,631 & 0.66 & 24,692 & 7,334 & 8,758 & 1.19 \\
Oct/11 & 123,45 & 35,41 & 50,027 & 1.41 & 47,134 & 14,25 & 16,858 & 1.18 \\
Nov/11 & 20,05 & 5,487 & 7,879 & 1.44 & 38,471 & 14,516 & 15,315 & 1.06 \\
Dec/11 & 16,9 & 8,973 & 7,283 & 0.81 & 13,923 & 9,699 & 4,052 & 0.42 \\
Jan/12 & 4,7 & 15,875 & 1,305 & 0.08 & 22,115 & 27,792 & 9,442 & 0.34 \\
Feb/12 & 50,15 & 8,8 & 19,835 & 2.25 & 21,098 & 21,762 & 8,673 & 0.40 \\
Mar/12 & 20,95 & 10,06 & 7,403 & 0.74 & 8,981 & 12,808 & 3,442 & 0.27 \\
Apr/12 & 85,45 & 44,87 & 36,834 & 0.82 & 10,208 & 18,535 & 4,824 & 0.26 \\
May/12 & 189,15 & 24,98 & 77,541 & 3.10 & 22,996 & 13,818 & 9,145 & 0.66 \\
June/12 & 39,5 & 36,675 & 17,401 & 0.47 & 18,994 & 18,57 & 6,581 & 0.35 \\
\hline
\end{tabular}

The zooplankton abundance between paired bucket and vertical haul samples.

$100 \%$ in terms of abundance, which also indicates higher equitability.

In general, low correlation values were found for both the Braycurtis (BC) similarity index representing the density and for the Sorensen
(SOR) and Jaccard (JAC) indices representing the zooplankton community composition (Table V). Nevertheless, some significant similarities were found per sampling site. Only sampling sites L1 and L4 had correlations $<0.6$ (Legendre and Legendre 


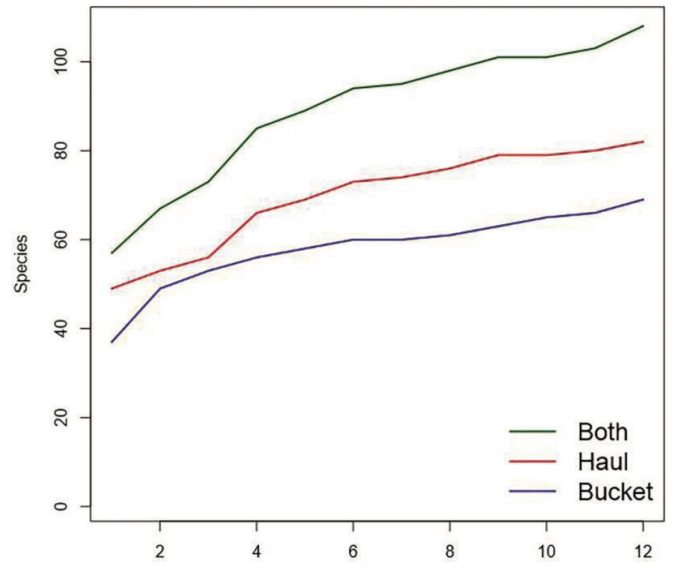

a.

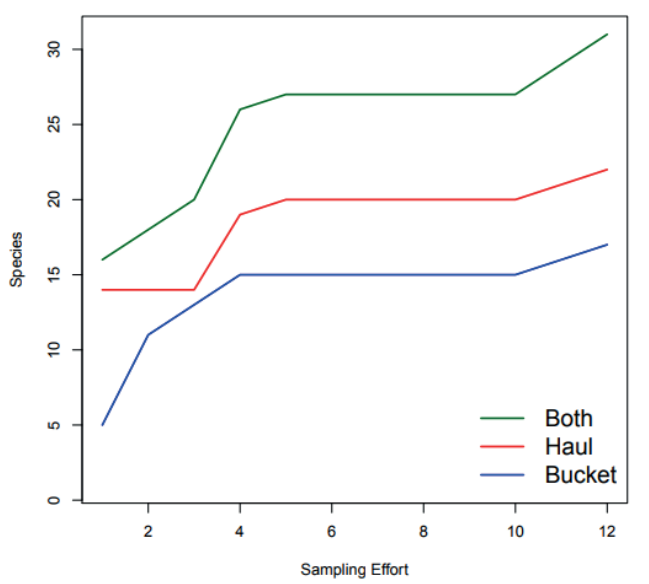

b.

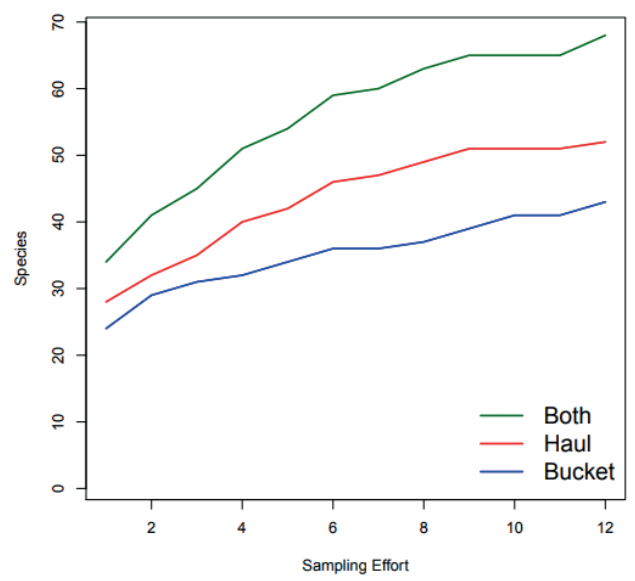

c.

Figure 2 - The collector's curves for vertical haul (red), bucket (blue) and both-intersection (green). a. all groups, b. cladocerans, c. rotiferans.
TABLE III

Monthly diversity and evenness for both strategies.

\begin{tabular}{llccc}
\hline & $\begin{array}{c}\text { Shannon-Wiener } \\
\text { diversity Index }\end{array}$ & \multicolumn{2}{c}{$\begin{array}{c}\text { Pielou's } \\
\text { evenness Index }\end{array}$} \\
\hline Month & Bucket & $\begin{array}{c}\text { Vertical } \\
\text { Haul }\end{array}$ & Bucket & Vertical Haul \\
\hline May/11 & 0.83 & 1.02 & 0.75 & 0.72 \\
June/11 & 0.89 & 0.97 & 0.83 & 0.66 \\
Aug/11 & 0.78 & 1.01 & 0,59 & 0.70 \\
Sept/11 & 0.96 & 1.01 & 0.67 & 0.70 \\
Oct/11 & 0.89 & 0.82 & 0.70 & 0.70 \\
Nov/11 & 1.03 & 1.13 & 0.84 & 0.76 \\
Dec/11 & 0.92 & 1.07 & 0.76 & 0.76 \\
Jan/12 & 0.96 & 1.08 & 0.84 & 0.78 \\
Feb/12 & 0.73 & 0.99 & 0.66 & 0.70 \\
Mar/12 & 0.93 & 0.95 & 0.77 & 0.68 \\
Apr/12 & 0.69 & 1.11 & 0.70 & 0.78 \\
May/12 & 0.61 & 0.95 & 0.49 & 0.68 \\
June/12 & 0.89 & 1.06 & 0.72 & 0.74 \\
\hline & & & & \\
\hline
\end{tabular}

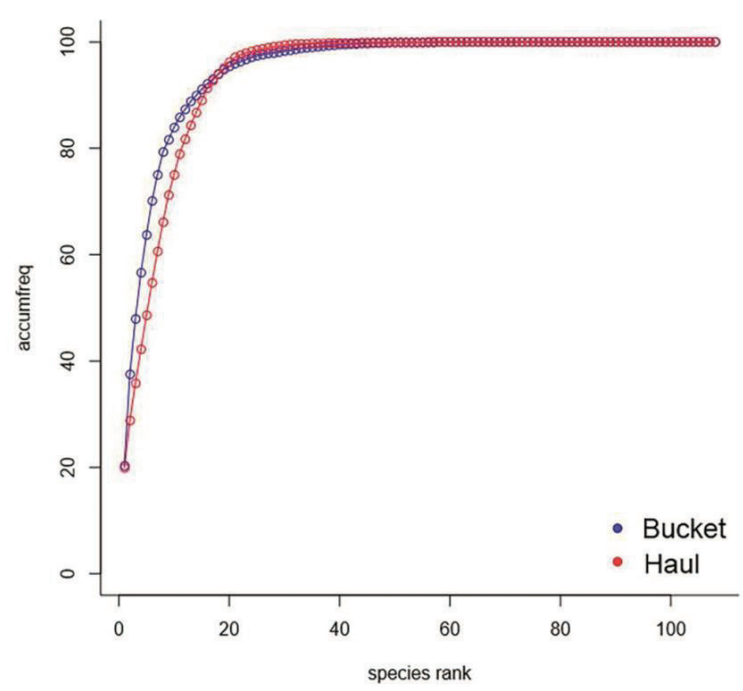

Figure 3 - K-dominance plot of zooplankton collected from Ribeirão das Lajes Reservoir from May/2011 to June/2012 using the two strategies. Accumulative frequency/y-axis and species rank/x-axis. The circles in the curves resent the rank in ascending order of abundance representativeness. 
TABLE IV

Taxa collected with bucket (a) and vertical haul (b). "Rank" of taxa from most abundant to representability of $1 \%$. Total "Abundance" found in ind $/ \mathrm{m}^{3}$. "Proportion $\%$ " is the percentage of the representation in terms of abundance. "Accumfreq\%" is an accumulative rank in terms of abundance.

\begin{tabular}{lcccc}
\hline (a) & \multicolumn{3}{c}{ Bucket } & \\
\hline Taxon & rank & Abundance & Proportion\% & Accumfreq\% \\
\hline Nauplius (Calanoida) & 1 & 303,283 & 20.3 & 20.3 \\
Kellicottia bostoniensis & 2 & 258,763 & 17.3 & 37.5 \\
Ptygura libera & 3 & 155,7 & 10.4 & 47.9 \\
Copepodite (Calanoida) & 4 & 129,463 & 8.6 & 56.6 \\
Nauplius (Cyclopoida) & 5 & 107,096 & 7.2 & 63.7 \\
Ceriodaphnia silvestrii & 6 & 95,105 & 6.4 & 70.1 \\
Keratella cochlearis & 7 & 73,05 & 4.9 & 75.0 \\
Copepodite (Cyclopoida) & 8 & 64,221 & 4.3 & 79.3 \\
Ptygura sp. & 9 & 35,033 & 2.3 & 81.6 \\
Conochilus unicornis & 10 & 34,45 & 2.3 & 83.9 \\
Daphnia gessneri & 11 & 27,7 & 1.9 & 85.8 \\
Keratella americana & 12 & 23 & 1.5 & 87.3 \\
Ceriodaphnia paradoxa & 13 & 21,983 & 1.5 & 88.8 \\
Adults(Calanoida) & 14 & 17,55 & 1.2 & 89.9 \\
Adults (Cyclopoida) & 15 & 17 & 1.1 & 91.1 \\
Conochilus coenobasis & 16 & 15,55 & 1.0 & 92.1 \\
\hline
\end{tabular}

\begin{tabular}{lcccc}
\hline (b) & \multicolumn{4}{c}{ Vertical haul } \\
\hline Taxon & Rank & Abundance & Proportion\% & Accumfreq\% \\
\hline Nauplius (Cyclopoida) & 1 & 235,415 & 19.9 & 19.9 \\
Ceriodaphnia paradoxa & 2 & 105,224 & 8.9 & 28.8 \\
Copepodite (Calanoida) & 3 & 82,928 & 7.0 & 35.8 \\
Copepodite (Cyclopoida) & 4 & 75,96 & 6.4 & 42.2 \\
Nauplius (Calanoida) & 5 & 75,576 & 6.4 & 48.6 \\
Kellicottia bostoniensis & 6 & 71,869 & 6.1 & 54.7 \\
Proales sp. & 7 & 70,15 & 5.9 & 60.6 \\
Ceriodaphnia silvestrii & 8 & 65,233 & 5.5 & 66.1 \\
Conochilus unicornis & 9 & 59,724 & 5.0 & 71.2 \\
Keratella cochlearis & 10 & 45,786 & 3.9 & 75.0 \\
Ascomorpha ovalis & 11 & 45,43 & 3.8 & 78.9 \\
Collotheca ornata & 12 & 33,62 & 2.8 & 81.7 \\
Adults (Cyclopoida) & 13 & 30,785 & 2.6 & 84.3 \\
Adults (Calanoida) & 14 & 28,125 & 2.4 & 86.7 \\
Ceriodaphnia cornuta & 15 & 27,491 & 2.3 & 91.3 \\
Conochilus dossuarius & 16 & 26,44 & 2.2 & 92.7 \\
Conochilus coenobasis & 17 & 16,725 & 1.4 & 94.0 \\
Testudinella patina & 18 & 15,257 & 1.3 & 95.1 \\
Bosmina hagmanni & 19 & 13,657 & 1.2 & 96.2 \\
Diaphanosoma brevireme & 20 & 13,388 & 1.1 & 97.1 \\
Daphnia gessneri & 21 & 10,481 & 1.0 &
\end{tabular}


1998). In these sites, community was considered similar with both samplers in terms of richness (SOR and JAC) and abundance (BC).

\section{DISCUSSION}

For many years, zooplankton at Ribeirão das Lajes reservoir was sampled using the subsurface bucket sampling strategy requested by the state agency in charge of monitoring water bodies in Rio de Janeiro State (FEEMA/INEA). Although this method is routinely used for several other freshwater systems, our results demonstrated that it underestimates zooplankton richness and community components of diversity. Thus, important information to a closer ecological analysis is lacking. Sampling with the bucket, on the other hand, overestimated the abundance of dominant species, which had the highest mean densities for the whole period, thus decreasing equitability.

Rotifers presented the highest richness for the whole period (69 taxa) in agreement with what is often reported for Brazilian reservoirs (Matsumura-Tundisi et al. 1990, Rocha et al. 1995, Zaganini et al. 2011, Paranhos et al. 2013). While rotifers dominated the bucket samples with $44 \%$ of the total abundance followed by copepods with $42.9 \%$, these, in turn, were more representative
$(44.7 \%)$ in vertical hauls followed by rotifers with $35.3 \%$. Cladocerans was the group with lowest contribution with both techniques: $13.1 \%$ with bucket and $19.5 \%$ with vertical haul. Community composition might have differed as a response of specific abilities of swimming and evasion among groups, being the high evasion rate characteristic of species with higher motility (Fleminger and Clutter 1965, Kankaala 1984, Hodgkiss 1977). This can be pointed out as another reason to obtain a comparatively lower abundance using vertical hauls. This is because more water comes in then goes out the net causing overflows. Besides, a faster towing speed increases filtration pressure on the mesh and consequently increases escapement of the smaller organisms by extrusion (Tranter and Smith 1968) like smaller rotifers collected only or in greater amounts by bucket (Table IV).

Large-bodied animals such as microcrustaceans were better sampled with the vertical haul and this might be related to the daily vertical migration of those individuals (Bezerra-Neto and Pinto-Coelho 2002). On the other hand, bucket mainly collected copepod nauplii and rotifers, which are often plentiful in freshwater systems and have lower evasion capacity. Even though the bucket is a cost and time efficient sampler, it

TABLE V

Concordance between sampling strategies (sub-surface/bucket and vertical haul). Concordance was performed using PCoA followed by Procrustes rotation and Protest significance test with 1000 permutations (BC: Bray Curtis index, SOR: Sorensen index, JAC: Jaccard index). Significant relationships $(p<0.5)$ in bold (a). Concordance performed per point between sampling strategies (sub-surface/bucket and vertical haul). Significant relationships $(p<0.5)$ in bold (b).

\begin{tabular}{cccccccc}
\hline (a) Sites & Protest BC & p.value & Protest SOR & p.value & Protest JAC & p.value \\
\hline All five sites & 0.21 & 0.12 & 0.19 & 0.21 & $\mathbf{0 . 3 0}$ & 0.01 \\
\hline (b) Sites & Protest BC & p.value & Protest SOR & p.value & Protest JAC & p.value \\
\hline L1 & $\mathbf{0 . 6 7}$ & 0.010 & $\mathbf{0 . 6 6}$ & 0.004 & $\mathbf{0 . 6 9}$ & 0.004 \\
L2 & 0.25 & 0.631 & 0.32 & 0.573 & 0.36 & 0.535 \\
L3 & 0.53 & 0.162 & 45 & 0.173 & 0.51 & 0.152 \\
L4 & $\mathbf{0 . 7 8}$ & 0.002 & $\mathbf{0 . 7 4}$ & 0.006 & $\mathbf{0 . 7 3}$ & 0.006 \\
L5 & 0.32 & 0.388 & 0.39 & 0.289 & 0.42 & 0.263 \\
\hline
\end{tabular}


also underestimated key-species of cladocerans. Among cladoceran species, such as Bosmina hagmanni, Bosmina longirostris, Bosminopsis deitersi, Ceriodaphnia cornuta, Daphnia gessneri, and Moina minuta typically cited as true-planktonic and pointed as dominant in tropical reservoirs (Lopes et al. 1997, Espíndola et al. 2000, Melão and Rocha 2000, Nogueira 2001, Sampaio et al. 2002, Serafim-Jr 2002, Serafim-Jr et al. 2003, Takahashi et al. 2005) were better sampled with the vertical haul while the bucket only collected three of them satisfactorily (Table IV). Other invertebrates were sampled by both strategies but attained higher densities when collected with the bucket. Chaoborus larvae were registered at high abundances at subsurface and positive correlations with K. bostoniensis populations have previously been detected by Havens (1990).

Both samplers showed the highest mean abundances between August and September, a period corresponding to the beginning of the thermal stratification of the reservoir, after winter mixing (Branco et al. 2009). At this time, nutrient concentrations on the surface, might not be limiting for phytoplankton growth, in turn supporting zooplankton assemblages. Chlorophyll- $a$ in Lajes Reservoir can increase as a result of increased nutrient concentrations (Soares et al. 2008) and water mixing (Guarino et al. 2005). The bucket overestimated the density of a few organisms, thus while increasing the density of some species it lowered community equitability although not significantly. Abundance variance to mean ratio provides a powerful tool for valid comparisons of zooplankton aggregation at different spatial sampling scales, and across ecosystems (PinelAlloul et al. 1988, Downing 1991). For the same number of samples the vertical haul achieved a more satisfactory level of precision (Downing et al. 1987, Pace et al. 1991) in the estimation of zooplankton abundance and richness. On the other hand, CV for subsurface samplings with the bucket was $>30 \%$ (Ferreira 1991) representing a more heterogeneous structure (Fleminger and Clutter 1965) and indicating a lower consistency as a sampler. In part, the differences may be related to the variation of filtered volume (KozlowskySuzuki and Bozelli 1998). While vertical hauls sample a variable volume depending on the depth of the euphotic zone, the bucket collects a fixed, though lower volume, thus losing much of the limnetic information especially at reservoir areas with greater depths. We detected that maximum values for abundance in bucket samplings from 4,700 individuals $\mathrm{m}^{-3}$ in October to 123,450 ind. $\mathrm{m}^{-3}$ in January (Table IIb) and we relate this to a distribution of plankton in spots at the reservoir due to its water retention time (Branco et al. 2009) and low hydrodynamics creating obstacles to the assemblages horizontal distribution (Tundisi et al. 2008).

Furthermore, the horizontal patchy zooplankton distribution can largely vary being the subsurface samples taken at specific spots where the plankton assemblages are aggregated or at non-occupied micro-region providing a lack of continuous datasets. In their natural environment, organisms tend to be distributed non-homogeneously and present considerable differences in their vertical and horizontal distribution, such as aggregate distribution (Hutchinson 1967, Stavn 1971). An explanation for the non-detection of the significant differences in the evenness between samplings would be the distribution of the majority of populations near the surface. In addition to being labor-intensive and time-consuming, conventional sampling methods using vertical integrating samplers have limitations in their ability to resolve both zooplankton specific- and general-scale patchiness. Few advanced technologies (acoustic devices, the Optical Plankton Counter (OPC), and video systems) have been tested in freshwater ecosystems (Smith et al. 1992, Schulze et al. 1992) but even so, more studies that detect the population 
aggregation level and how they are organized in the water body (microdistribution studies) are needed.

Although species accumulation curves showed a greater efficiency of vertical haul in community sampling summing up both sampling efforts (green curve) the efficiency of collecting species at the reservoir was improved (Fig. 2). If species accumulation curves reach a point where increasing collection effort does not imply an increase in the number of species, this means that approximately all the richness of the area was sampled, which did not occur for any of the methods used. Not even the use of both methods resulted in a plateau reaching stability, encompassing 133 taxa, although it better represents the community by complementarity of the strategies. For Brazilian lakes, the only comparative study done elected the bump as an efficient technique for zooplankton sampling (KozlowskySuzuki and Bozelli 1998). Even the vertical haul being able to collect more species quicker, being the curve with the highest asymptote and therefore the most diverse. Samplings comprising only one strategy were considered underestimations when compared to the use of both to access total species richness (Fig. 2).

Spatially, the Protest indicates that the sampling strategies differed in abundance and composition of zooplankton at most points sampled. Notwithstanding, the points L1 and L4 presented positive correlation therefore presenting significant similarity. We can suggest that the community could be more similar in site L1 because its shallow condition and influence of the main tributary, with a mean depth of 1 meter and euphotic zone of a few centimeters. Site L4 is located at the dam region where the reservoir has the highest average depth, 40 meters, with clean water and low turbidity, consequently with a large euphotic zone. In this region, due a low influence of the main tributary, there are low content of nutrients and higher water transparency (Guarino et al. 2005). According to Soares et al. (2008) spatial heterogeneity is stronger than the seasonal variability in Lajes Reservoir due to the long water retention time. Besides that, the low turbidity at the dam can be suggested to increase fish predation on zooplankton, explaining a lower total abundance of the community in the water column. Several authors have already reported an important consumption of zooplankton by fish in Lajes Reservoir (Dias et al. 2005, Ferreira et al. 2013, Lopes et al. 2016).

The features of the water column of the reservoir at the dam can also help to explain the similar samplings done by surface collection and vertical haul at this place. Lajes Reservoir presents a mixing depth of 15 meters (Branco et al. 2009) and the length of the vertical hauls were related to water transparency (the limit of euphotic zone) that in the dam area is greater than the mixing depth. With the assumption that zooplankton would be homogeneously dispersed in the mixing zone at this site, there would be smaller differences between the existing communities on the surface and along the area sampled by the vertical haul, explaining why this last and the bucket sampled similar communities qualitatively and quantitatively (Table Vb).

All results corroborate our expectations that sampling methods brings up structures of different communities, being dominated by one group or another. According to our study, the use of the bucket in samplings of shallow environments is advised due to the practicality and the fact that there are no significant differences for the abundance and richness of the taxa. In these shallow places, it is still difficult to use the net because of the difficulty of carrying the haul, being a place with high hydrodynamics.

In the present study, we note the expansion of Kellicottia bostoniensis as an example of bioinvasions into fresh waters as a result of human activity (Dumont 1983, Pejler 1998). Their maintenance and good adaptability in tropical environments (Landa et al. 2002) indicates high ecological plasticity due to opportunistic behavior 
(Talamoni 1995) and the presence of a lorica with well-developed ventral and dorsal spines that protects against predation (Havens 1990). This species can live under conditions of oxygen deficiency and often occurs in the hypolimnion of deep lakes (Eloranta 1998, Ivanova and Telesh 2004). The high numerical results in subsurface can indicate an improvement in their fitness due to more dissolved oxygen in surface layers or even a niche shift of this invasive species (Silva et al. 2016). This rotifer species inhabits water-bodies with a trophic status ranging from oligo- to eutrophic (Zhdanova and Dobrynin 2011) including Brazilian reservoirs (Bezerra-Neto et al. 2004, Peixoto et al. 2010). The abundance of $K$. bostoniensis was 490,000 ind. $\mathrm{m}^{-3}$ in the epilimnion and reached 2 million ind. $\mathrm{m}^{-3}$ in the hypolimnion of an oligotrophic reservoir (Ivanova and Telesh 2004). Differently from those authors we found that the invader K. bostoniensis appears as the second most representative organism contributing with $17.3 \%$ of the total and reached 258,763.0 ind. $\mathrm{m}^{3}$ in subsurface samples (Table IVa) while with the vertical haul the representativeness is around $6.1 \%\left(71,869.0\right.$ ind $\left.^{-3}\right)$. Although studies point to a positive correlation of abundance with trophic degree (Landa et al. 2002) our study shows the interpretation may be associated with the sampler type, suggesting micro-distribution studies of the species.

Comparing vertically integrated versus surface sampling methods (Clark et al. 2001, Richardson et al. 2004) concluded that differences in sampling depth could not be responsible for much of the observed differences in abundance between two sampling methodologies. We suppose that the water column depth may not influence the sampling efficiency of the vertical haul or maybe not substantially revealing the influence of both vertical and horizontal distribution (Tundisi et al. 2008).

Several studies have examined the relationship between theabundanceof zooplankton, waterquality and trophic status of reservoirs, all emphasizing that composition and community structure may be an indicative of limnological conditions of the water body (Andronikova 1996, Attayde and Bozelli 1998). In this sense, the improvement of the sampling technique is an important step to analysis of water quality and biodiversity from trustworthy data. Biomass can also be used and it is based on the dominance of individuals and their contributions in terms of carbon. From this study, community sampled by haul, with dominant large-sized animals could reflect closely in terms of biomass the patterns known for reservoirs with the same characteristics (Matsumura-Tundisi et al. 1989, Sendacz et al. 2006). It is interesting to propose here another methodological study comparing samplers using graphical distributions of dominance in abundance and biomass among ranked species, extracting information on species dominance patterns (Clarke and Warwick 1994). It would then be expected that both types of data collectors together should evaluate the trophic state of the reservoir, its ecological structure and its pollution disturbs more properly. We considered that the method of collecting zooplankton at the subsurface adopted in systematic monitoring in many eutrophic reservoirs due to net clogging significantly subsamples zooplankton diversity in the limnetic area reservoir of lower trophic status.

Finally, no single sampling device is able to sample all the zooplankton components at any one time, leading us to select which is most appropriate to particular studies. We have shown that surface samples collected by bucket and vertically integrated samples collected by the zooplankton net provide different results on the zooplankton community and that different components of the community are sampled with different degrees of efficiency. In addition, we suggest the use of both strategies as previously proposed for temperate regions (Hodgkiss 1977, Karjalainen et al. 1996, Livings et al. 2010, Pitois 2016) especially for 
qualitative studies where both methods can record differently the dominant taxa and community attributes.

\section{ACKNOWLEDGMENTS}

This work was supported by Universidade Federal do Estado do Rio de Janeiro; Light Energia S.A. and Coordenação de Aperfeiçoamento de Pessoal de Nível Superior (CAPES). We thank all people who contributed to the long-term data set of Ribeirão das Lajes reservoir, in special Priscila G. Rosa and Leonardo C. Souza. Insightful comments by $\mathrm{PhD}$ Tatiana Fabrício Maria and Rafael dos Santos Henrique improved the manuscript.

\section{REFERENCES}

ALMEIDA VLS, DANTAS ÊW, MELO-JÚNIOR M, BITTENCOURT-OLIVEIRA MC AND MOURA AN. 2009. Zooplanktonic community of six reservoirs in northeast Brazil. Braz J Biol 69: 79-87.

ALMEIDA VLS, LARRAZÁBAL MEL, MOURAAN AND MELO-JÚNIOR M. 2006. Rotifera das zonas limnética e litorânea do reservatório de Tapacurá, Pernambuco, Brasil. Iheringia Sér Zool 96: 445-451.

ANDRONIKOVA IN. 1996. Structural-functional organization of zooplankton in lakes' ecosystem of different trophic types, Nauka, St. Petersburg. Hydrobiologia 322: 173-179.

ATTAYDE JL AND BOZELLI RL. 1998. Assessing the indicator properties of zooplankton assemblages to disturbance gradients by canonical correspondence analysis. Can J Fish Aquat Sci 55: 1789-1797.

BEZERRA-NETO JF, AGUILA LA, LANDA GG AND PINTO-COELHO RM. 2004. The exotic rotifers Kellicotia bostoniensis (Rousselet,1908) (Rotifera:Brachionidae) in the zooplankton community in the tropical reservoir. Lundiana 5: 151-153.

BEZERRA-NETO JF, MELLO NAST, MAIA-BARBOSA PM AND PINTO-COELHO RM. 2009. The role of predation in the diel vertical migration of zooplankton in two tropical freshwaters ecosystems. Acta Limnol Bras 21: 45-56

BEZERRA-NETO JF AND PINTO-COELHO RM. 2002. A influência da larva de Chaoborus brasiliensis (Theobald, 1901) (Diptera, Chaoboridae) na distribuição vertical da comunidade zooplanctônica da lagoa do Nado, Belo Horizonte, Estado de Minas Gerais. Acta Sci Biol Sci 24: 337-344.
BRANCO CWC, KOZLOWSKY-SUZUKI B, SOUSAFILHO I, GUARINO ASW AND ROCHA RJ. 2009. Impact of climate on the vertical water column structure of Lajes Reservoir (Brazil): A tropical reservoir case. Lakes Reservoirs: Res Manag (Online) 14: 175-191.

BRANCO CWC, ROCHA MIA, PINTO GFS, GÔMARA GA AND DE FILIPPO R. 2002. Limnological features of Funil reservoir (RJ, Brazil) and indicator properties of rotifers and cladocerans of the zooplankton community. Lakes Reservoirs: Res Manag 7: 87-92.

BRANCO CWC AND SENNA PAC. 1996. The phytoplankton community of Paranoá Reservoir: Taxonomic features of the species. In: IV Congresso Latino-Americano de Ficologia, Caxambu. Resumos do IV Congresso Latino-Americano de Ficologia 3: 201-201.

CLARK RA, FRID CLJ AND BATTEN S. 2001. A critical comparison of two long-term zooplankton time series from the central-west North Sea. J Plankton Res 23: 27-39.

CLARKE MR AND WARWICK RM. 1994. Change in Marine Communities. An Approach to Statistical Analysis and Interpretation. Natural Environment Research Council, Bournemouth.

DI BERNARDI R. 1984. Methods for the estimation of zooplankton abundance. In: Downing JA and Rigler FH (Eds), A Manual on Methods in Assessment of Secondary Productivity in Fresh Waters. IBP Handbook No. 17, 2nd ed., Blackwell, Oxford, p. 59-86.

DIAS ACMI, BRANCO CWC AND LOPES VG. 2005. Estudo da dieta natural de peixes no reservatório de Ribeirão das Lajes, Rio de Janeiro, Brasil. Acta Sci Biol Sci 27: 355-364.

DOWNING JA. 1991. The effect of habitat structure on the spatial distribution of freshwater invertebrate populations. In: Bell SS, Mccoy ED and Mushinsky H (Eds), Habitat structure: the physical arrangement of objects in space. Chapman and Hall, London, p. 87-106.

DOWNING JA, PÉRUSSE M AND FRENETTE MY. 1987. Effect of inter-replicate variance on zooplankton sampling design and data analysis. Limnol Oceanogr 32: 673-680.

DUMONT HJ. 1983. Biogeography of rotifers. Hydrobiologia 104: 19-30.

ELORANTA P. 1988. Kellicottia bostoniensis, a plankton rotifer species new to Finland. Zool Fenn 25: 249-252.

ESPÍNDOLA ELG, MATSUMURA-TUNDISI T, RIETZELER AC AND TUNDISI JG. 2000. Spatial heterogeneity of the Tucuruí Reservoir (State of Pará, Amazonia, Brazil) and the distribution of zooplanktonic species. Rev Bras Biol 60: 179-194.

ESTEVES FA. 2011. Gênese dos ecossistemas lacustres. Fundamentos de Limnologia. Rio de Janeiro: Editora Interciência, $3^{\text {a }}$ ed., p. 83-112.

EVANS MS AND SELL DW. 1983. Zooplankton sampling strategies for environmental studies. Hydrobiologia 99: 215-223. 
EVANS MS AND SELL DW. 1985. Mesh size and collection characteristics of $50-\mathrm{cm}$ diameter conical plankton nets. Hydrobiologia 122: 97-104.

FERREIRA GL, LOPES VG, GOMES JHC AND BRANCO CWC. 2013. Condition factor and diet of the catfish Loricariichthys castaneus (Castelnau, 1855): gender differences in three tropical reservoirs. Stud on Neotrop Fauna and Environ 48: 190-198.

FERREIRA PV. 1991. Estatística experimental aplicada à agronomia. Maceió, EDUFAL, p. 437.

FLEMINGER A AND CLUTTER RI. 1965. Avoidance of towed nets by zooplankton. Limnol Oceanogr 10: 96-104.

GUARINO AWS, BRANCO CWC, DINIZ GP AND ROCHA R. 2005. Limnological Characteristics of an Old Tropical Reservoir (Ribeirão das Lajes Reservoir, RJ, Brazil). Acta Limnol Bras 17: 129-141.

HANEY JF AND HALL DJ. 1973. Sugar-coated Daphnia: A preservation technique for Cladocera. Limnol Oceanogr 18: 331-333.

HAVENS KE. 1990. Chaoborus predation and zooplankton community structure in a rotifer-dominated lake. Hydrobiologia 198: 215-226.

HODGKISS I. 1977. The use of simultaneous sampling bottle and vertical net collections to describe the dynamics of a zooplankton populations. Hydrobiologia 52: 197-205.

HUTCHINSON GH. 1967. A treatise on Limnology. Introduction to lake biology and limnoplankton. J Wiley \& Sons, Inc., New York, p. 1115.

HWANG JS, KUMAR R, DAHMS HU, TSENG LC AND CHEN QC. 2007. Mesh size affects abundance estimates of Oithona spp. (Copepoda, Cyclopoida). Crustaceana 80: 827-837.

ICANBERRY JW AND RICHARDSON RW. 1973. Quantitative sampling of live zooplankton with a filter pump system. Limnol Oceanogr 18: 333-335.

IVANOVA MB AND TELESH IV. 2004. Seasonal and interannual dynamics of planktonic rotifers and Crustacea in appropriatenesses of a hydrobiological conditions of different reservoirs, Moscow: Nauchny Mir, p. 71-83.

JACKSON DA. 1995. PROTEST: a Procrustean randomization test of community environment concordance. Écoscience 2: 297-303.

JENNINGS S, PINNEGAR JK, POLUNIN NVC AND WARR KJ. 2001. Impacts of trawling disturbance on the trophic structure of benthic invertebrate communities. Mar Ecol Prog Ser 213: 127-142.

JEPPESEN E ET AL. 2011. Zooplankton as indicators in lakes: A scientific-based plea for including zooplankton in the ecological quality assessment of lakes according to the European Water Framework Directive (WFD). Hydrobiologia 676: 270-297.

KANKAALA P. 1984. A quantitative comparison of two zooplankton sampling methods, a plankton trap and a towed net, in the Baltic. Int Revue ges Int Rev Hydrobiol und Hydrog 69: 277-287.

KARJALAINEN J, RAHKOLA M, VILJANEN M, ANDRONIKOVA IN AND AVINSKII VA. 1996. Comparison of methods used in zooplankton sampling and counting in the joint Russian-Finnish evaluation of the trophic state of Lake Ladoga. Hydrobiologia 322: 249253.

KEPPELER EC. 2003. Abundance of zooplankton from different zones (pelagic and littoral) and time periods (morning and night) in two Amazonian meandering lakes. Acta Sci Biol Sci 25: 287-297.

KOZLOWSKY-SUZUKI B AND BOZELLI R. 1998. Evaluation of the efficiency of three samplers on estimating the zooplankton abundance of Cabiúnas lagoon. In: Esteves FA (Ed), Ecologia das lagoas costeiras do parque nacional da restinga de Jurubatiba e do Município de Macaé (RJ), p. 442.

LAHR DJG AND LOPES SGBC. 2006. Morphology, Biometry, Ecology and Biogeography of Five Species of Difflugia Leclerc, 1815 (Arcellinida: Difflugiidae), from Tiete River, Brazil. Acta Protozool 45: 77-90.

LANDA GG, AGUILA LMR AND PINTO-COELHO RM. 2002. Distribuição espacial e temporal de Kellicottia bostoniensis (Rousselet, 1908) (Rotifera) em um grande reservatório tropical (reservatório de Furnas), Estado de Minas Gerais, Brasil. Acta Sci Biol Sci 24: 313-319.

LEGENDRE P AND LEGENDRE FJ. 1998. Numerical Ecology. Developments in Environmental Modelling. Elsevier Science. vol. 24.

LIVINGS ME, SCHOENEBECK CW AND BROWN ML. 2010. Comparison of Two Zooplankton Sampling Gears in Shallow, Homogeneous Lakes. The Prairie Naturalist 42(1/2).

LOGAN BE. 1993. Theroretical analysis size distributions determined with screens and filters. Limnol Oceanogr 38: 372-381.

LOPES RM, LANSAC-TÔHA FA, DO VALE R AND SERAFIM-JR M. 1997. Comunidade zooplanctônica do reservatório de Segredo. In: Agostinho AA and Gomes LC (Eds), Reservatório de Segredo bases ecológicas para o manejo. Maringá, PR. EDUEM, 387 p.

LOPES VG, CASTELO BRANCO CW, KOZLOWSKYSUZUKI B, SOUSA-FILHO IF, SOUZA LCE AND BINI LM. 2017. Predicting temporal variation in zooplankton beta diversity is challenging. PLoS ONE 12(11): e0187499.

LOPES VG, NESSIMIAN JL, DA-SILVA ER, GOMES JHC, DIAS ACIM, SOUZA LC AND BRANCO CWC. 2016. Habitat heterogeneity on feeding habit of two sympatric and congeneric characid fishes in two tropical reservoirs. Iheringia Sér Zool 106: e2016012. 
LUDWIG JA AND REYNOLDS JF. 1988. Statistical ecology: a primer on methods and computing. J Wiley \& Sons, New York.

MACK HR, CONROY JD, BLOCKSOM KA, STEIN RA AND LUDSIN SA. 2012. A comparative analysis of zooplankton field collection and sample enumeration methods. Limnol Oceanogr Meth 10: 51-43.

MAIA-BARBOSA PM AND BOZELLI RL. 2005. Lengthweight relationships for five cladoceran species in an Amazonian Lake. Braz Arch Biol Technol 48: 303-308.

MAIA-BARBOSA PM, ESKINAZI-SANT'ANNA EM AND BARBOSA FAR. 2003. Zooplankton composition and vertical distribution in a tropical, monomictic lake (Dom Helvécio lake, Southeastern Brazil). Acta Limnol Bras 15: 65-74.

MATSUMURA-TUNDISI T, RIETLER AC AND ESPÍNDOLA ELG. 1990. Predation on Ceriodaphnia cornuta and Brachionus calyciflorus by two Mesocyclops species coexisting in Barra Bonita Reservoir. Hydrobiologia 198: 141-151.

MATSUMURA-TUNDISI T, RIETZLER AC AND TUNDISI JG. 1989. Biomass (dry weight and carbon content) of plankton Crustacea from Broa reservoir (São Carlos, SP, Brasil) and its fluctuations across one year. Hydrobiologia 179: 229-236.

MCGOWAN JA AND FRAUNDORF VJ. 1966 The relationship between size of net used on estimates of zooplankton diversity. Limnol Oceanogr 11: 456-469.

MELÃO MGG AND ROCHA O. 2000. Productivity of zooplankton in a tropical oligotrophic reservoir over short period of time. Verh Internat Ver für theor und angew Limnol 27: 2879-2887.

NADAI RAND HENRY R. 2009. Temporary fragmentation of a marginal lake and its effects on zooplankton community structure and organization. Braz J Biol 69: 819-835.

NOGUEIRA MG. 2001. Zooplankton composition, dominance and abundance as indicator of environmental compartmentalization in Jurumirim Reservoir (Paranapanema River), São Paulo, Brazil. Hydrobiologia 455: 1-18.

NOGUEIRA MG, OLIVEIRA PCR AND DE BRITTO YT. 2008. Zooplankton assemblages (Copepoda and Cladocera) in a cascade of reservoirs of a large tropical river (SE Brazil). Limnetica 27: 151-170.

PACE ML, FINDLAY SEG AND LINTS D. 1991. Variance in zooplankton samples: evaluation of a predictive model. Can J Fish Aquat Sci 48: 146-151.

PARANHOS JDN, ALMEIDA VLDS, SILVA FILHO JP, PARANAGUÁ MN, MELO-JÚNIOR M AND NEUMANN-LEITÃO S. 2013. The zooplankton biodiversity of some freshwater environments in Parnaíba basin (Piauí, Northeastern Brazil). Braz J Biol 73: 125134.

PEIXOTO RS, BRANDÃO LPM, VALADARES CDF AND BARBOSA PMM. 2010. Occurrence of Kellicottia bostoniensis (Rousselet, 1908) and Mesocyclops ogunnus Onabamiro, 1957 in lakes of the Middle River Doce, MG, Brazil. Acta Limnol Bras 22: 356-360.

PEIXOTO RS, SÁ CEM, GUIMARÃES AS AND MAIABARBOSA PM. 2008. Seasonal fluctuations of the microcrustacean assemblages in the littoral zone of Lake Dom Helvécio (Parque Estadual do Rio Doce, MG). Acta Limnol Bras 20: 213-219.

PEJLER B. 1998. History of rotifer research in northern Europe. Hydrobiologia 387/388: 1-8.

PERES-NETO PR AND JACKSON DA. 2001. How well do multivariate data sets match? The advantages of a Procustean superimposition approach over the Mantel test. Oecologia 129: 169-178.

PINEL-ALLOUL B, DOWNING JA, PÉRUSSE M AND CODIN-BLUMER G. 1988. Spatial heterogeneity in freshwater zooplankton: variation with body size, depth, and scale. Ecology 69: 1393-1400.

PINTO-COELHO RM, BEZERRA-NETO JF, GIANI A, MORAIS CA AND CARVALHO EA. 2005. The nutritional status of zooplankton in a tropical reservoir: food quality and community structure. Braz J Biol 65: $1-13$.

PITOIS SG, BOUCH P, CREACH V AND VAN DER KOOIJ J. 2016. Comparison of zooplankton data collected by a continuous semi-automatic sampler (CALPS) and a traditional vertical ring net. J Plankton Res 38: 931-943.

RAHKOLA-SORSA M, VOUTILAINEN A AND VILJANEN M. 2014. Intercalibration of an acoustic technique, two optical ones, and a simple seston dry mass method for freshwater zooplankton sampling. Limnol Oceanogr Meth 12: 102-113.

RICCARDI N. 2010. Selectivity of plankton nets over mesozooplankton taxa: implications for abundance, biomass and diversity estimation. J Limnol 69: 287-296.

RICHARDSON AJ, JOHN EH, IRIGOIEN X, HARRIS RP AND HAYS GC. 2004. How well does the continuous plankton recorder (CPR) sample zooplankton? A comparison with the Longhurst Hardy Plankton Recorder (LHPR) in the northeast Atlantic. Deep Sea Res Part I 51: 1283-1294.

ROCHA MIA, BRANCO CWC, SAMPAIO GF, GÔMARA GA AND DE FILIPPO R. 2002. Spatial and temporal variation of limnological features, Microcystis aeruginosa and zooplankton in an eutrophic reservoir (Funil Reservoir, Rio de Janeiro). Acta Limnol Bras 14: 73-86.

ROCHA O, SENDACZ S AND MATSUMURA-TUNDISI T. 1995. Composition, biomass and productivity of zooplankton in natural lakes and reservoirs of Brazil. In: Tundisi JG, Bicudo CEM and Matsumura-Tundisi T. Limnology in Brazil. São Paulo: ABC/SBL, p. 151-166.

SAMPAIO EV, ROCHA O, MATSUMURA-TUNDISI T AND TUNDISI JG. 2002. Composition and abundance 
of zooplankton in the limnetic zone of the Paranapanema River, Brazil. Braz J Biol 62: 525-545.

SANTOS-WISNIEWSKI MJ AND ROCHA O. 2007. Spatial distribution and secondary production of Copepoda in a tropical reservoir: Barra Bonita, SP, Brazil. Braz J Biol 67: 223-233.

SCHULZE PC ET AL. 1992. Video Systems for in situ studies of zooplankton. Arch Hydrobiol Beih Ergebn Limnol 36: $1-21$.

SCHWOERBEL J. 1970. Methods in Hydrobiology. Freshwater Biology, Pergamon Press, Oxford, London, p. 200.

SENDACZ S, CALEFFI S AND SANTOS-SOARES J. 2006. Zooplankon biomass of reservoirs in different trophic conditions in the state of São Paulo, Brazil. Braz J Biol 66: 337-350.

SERAFIM-JR, M. 2002. Efeitos do represamento em um trecho do médio rio Iguaçu sobre a estrutura e dinâmica da comunidade zooplanctônica. Tese de Doutorado, Universidade Estadual de Maringá, Maringá, Paraná, 51 p.

SERAFIM-JR M, NEVES GP, DE BRITO L AND GHIDINI A. 2003. Composição da comunidade zooplanctônica de um reservatório eutrofizado do Altíssimo Rio Iguaçu, região metropolitana de Curitiba, Paraná, Brasil. In: IV Seminário do Projeto Interdisciplinar de pesquisa em eutrofização de águas de abastecimento público na bacia do Altíssimo Iguaçu, Curitiba - PR, p. 27-29.

SERAFIM-JR M, PERBICHE-NEVES G, BRITO L, GHIDINI AR AND CASANOVA SMC. 2010. Variação espaço-temporal de Rotíferos em um reservatório eutrofizado no sul do Brasil. Iheringia Sér Zool 100: 233241.

SILVA DP, VILELA B, BUZATTO BA, MOCZEK AP AND HORTAL J. 2016. Contextualized niche shifts upon independent invasions by the dung beetle Onthophagus taurus. Biol Invasions 18: 3137-3148.

SILVA LHSD, ARCIFA MS, SALAZAR-TORRES G AND HUSZAR VLM. 2014. Tilapia rendalli increases phytoplankton biomass of a shallow tropical lake. Act Limnol Bras 26: 429-441.

SIMÕES NR AND SONODA SL. 2009. Estrutura da assembleia de microcrustáceos (Cladocera e Copepoda) em um reservatório do semi-árido Neotropical, Barragem de Pedra, Estado da Bahia, Brasil. Acta Scien Biol Sci 31: 89-95.

SMITH SL, PIEPER RE, MOORE MV, RUDSTAM LG, GREENE CH, ZAMON JE, FLAGG CN AND WILHAMSON CE. 1992. Acoustic the techniques for the in situ observation of zooplankton. Arch Hydrobiol Beih Ergebn Limnol 36: 23-43.

SOARES MCS, MARINHO MM, HUSZAR VLM, BRANCO CWC AND AZEVEDO SMFO. 2008. The effects of water retention time and watershed features on the limnology of two tropical reservoirs in Brazil. Lakes Reservoirs: Res Manag 13: 257-269.
STARLING FL. 2000. Comparative study of the zooplankton composition of six lacustrine ecosystems in central Brazil during the dry season. Rev Bras Biol 60: 101-111.

STAVN RH. 1971. The Horizontal-Vertical Distribution Hypothesis: Langmuir Circulations and Daphnia Distributions. Limnol Oceanogr 16: 453-466.

TAKAHASHI EM, LANSAC-TÔHA FA, VELHO LFM AND BONECKER CC. 2005. Longitudinal distribution of cladocerans (Crustacea) in a Brazilian tropical reservoir. Acta Limnol Bras 17: 257-265.

TALAMONI JL. 1995. Estudo comparativo das comunidades planctônicas de lagos de diferentes graus de trofia e uma análise de microcrustáceos. Tese de Doutorado. Departamento de Ciências Biológicas, Universidade Federal de São Carlos, São Carlos, SP, 305 p.

TONOLLI V. 1971. Zooplankton. In: Edmondson WT and Winberg GG (Eds), IBP Handbook A Manual on Methods for the Assessment of Secondary Productivity in Fresh Waters. Blackwell, Oxford., No. 17, p. 1-14.

TRANTER DJ AND SMITH PE. 1968. Filtration performance, in: Zooplankton sampling: review papers of the proceedings of the symposium on the hydrodynamics of zooplankton sampling. Monog Oceanog Meth 2: 27-56.

TUNDISI JG, MATSUMURA-TUNDISI T AND ABE DS. 2008. The ecological dynamics of Barra Bonita (Tiete River, SP, Brazil) reservoir: implications for its biodiversity. Braz J Biol 68: 1079-1098.

VANNUCCI M. 1968. Loss of organisms through the meshes. Monog Oceanog Meth 2: 77-86.

VIEIRA LCG, VITAL MCV, FERNANDES APC, BONECKER CC, NABOUT JC, KRAUS CN, BERNARDI JVE, VELHO LFM AND BINI LM. 2017. Sampling sufficiency for estimating zooplankton diversity in neotropical floodplain lakes. Lakes Reservoirs: Res Manag 22: 190-196.

WAICHMAN AV, GARCÍA-DÁVILA CR, HARDY ER AND ROBERTSON BA. 2002. Composição do zooplâncton em diferentes ambientes do lago Camaleão, na ilha da Marchantaria, Amazonas, Brasil. Acta Amaz 32: 339-347.

WU CJ, SHIN CM AND CHIANG KP. 2011. Does the mesh size of the plankton net affect the result of statistica analysis of the relationship between the copepod community and water masses. Crustaceana 84: 1069-1083.

ZAGANINI RL, PERBICHE-NEVES G AND NALIATO GDAO. 2011. Baixa diversidade de zooplâncton na desembocadura de uma represa eutrófica (SP, Brasil): reflexo da poluição? Estud Biol 32/33(76/81): 17-24.

ZHDANOVA SM AND DOBRYNIN AE. 2011. Kellicottia bostoniensis (Rousselet, 1908) (Rotifera, Brachionidae) in water bodies of European Russia. Inland Wat Biol 4: $39-46$. 